Volume 10 No. 2 September 2019

P-ISSN 2086-6178 E-ISSN 2579-3292

http://ejournal.bsi.ac.id/ejurnal/index.php/jkom

\title{
Management Humas BKKBN Dalam Membentuk Citra Positif Melalui Keluarga Kurang Mampu
}

\author{
Achmad Haikal \\ Universitas Bina Sarana Informatika \\ e-mail: achmad.aik@bsi.ac.id
}

Cara Sitasi: Haikal, A (2019). Management Humas BKKBN Dalam Membentuk Citra Positif Melalui Keluarga Kurang Mampu. Jurnal Komunikasi, 10(2), 99-107

\begin{abstract}
In this era of globalization, the role of $P R$ is very important in building a positive image of a company. By optimizing the role of public relations we can establish a good relationship, harmony and understanding between the external public and public companies.Bureau of Law, Organization, and Public Relations $P R$ is also in charge of affairs in his role for the BKKBN, provide a good solution for the office. When the first program-planning program managed through education and socialization of safari. But now look kuramg hit in the era of globalization and the increasingly advanced technology.Then in accordance with one of the scope of duties and functions of the Bureau of Law, Organization, and Public Relations program is disseminating publications through print media. It is intended that BKKBN hum included into the national family planning program can be heard and conveyed to all parts of Indonesia and provide positive imagery for the $B K K B N$.
\end{abstract}

Keywords: Public Relations, Management, BKKBN

\section{PENDAHULUAN}

Salah satu tujuan humas dalam sebuah lembaga atau institusi adalah membantu mengubah pola berpikir masyarakat menjadi lebih baik. Humas mempunyai banyak cara dalam mengapresiasikan suatu informasi melalui berbagai media.

Seiring berkembangnya zaman, pemberitaan atau informasi-informasi yang dapat menjadi salah satu pengaruh berubahnya pola pikir masyarakat sangat beragam. Salah satunya adalah publikasi melalui media cetak yaitu surat kabar. Humas BKKBN Pusat menggunakan surat kabar menjadi salah satu media publikasi untuk mensosialisasikan program-program BKKBN. Tujuannya adalah sebagai alat untuk pencerahan agar masyarakat dapat mengetahui informasiinformasi melalui media cetak khususnya surat kabar.

Dalam program acara diskusi dua mingguan ini, khusus media berperan penting sebagai suatu alat untuk pencerahan kepada masyarakat tentang isu citra $\mathrm{BKKBN}$, isu tentang program $\mathrm{KB}$ sehingga bisa di adop oleh masyarakat menjadi suatu perilaku dan perbuatan dalam upaya membutuhkan keluarga kecil bahagia sejahtera.

Badan kependudukan dan keluarga berencana nasional (BKKBN) lembaga pemerintahan non departemen (LPND) yang berada di bawah dan bertanggung jawab langsung kepada presiden. Peraturan presiden tentang badan kependudukan dan keluarga berencana nasional. Sesuai dengan undang- undangyang diberikan presiden nomor 52 tahun 2009 tentang perkembangan kependudukan dan pembangunan keluarga,dan peraturan presiden dirubah menjadi nomor 62 tahun 2010 tentang badan kependudukan dan keluarga berencana nasional.

Sesuai dengan pasal 1 badan kependudukan dan keluarga berencana nasional yang selanjutnya dalam peraturan presiden ini disebut dengan BKKBN adalah lembaga pemerintahan non kementerian yang berada dibawah dan bertanggung jawab kepada presiden melalui menteri yang bertanggung jawab di bidang kesehatan. BKKBN mempunyai tugas melaksanakan tugas pemerintah di bidang pengendalian penduduk dan penyelenggaraan keluarga berencana.

Masalah pokok yang dihadapi adalah merubah sikap perilaku masyarakat dari pandangan yang negatif tentang alat kontrasepsi menjadi pandangan yang positif tentang keluarga kecil bersejahtera, karena masyarakat mempunyai asumsi banyak anak banyak rezeki, pola pikir itu susah dirubah karena sudah menjadi suatu budaya.

Dalam hal ini membutuhkan proses, memerlukan waktu, sehingga proses dan waktu itu sedikit di percepat BKKBN tidak melakukan sendiri salah satunya bekerjasama dengan jajaran media. Karena itu kita mempunyai upaya kegiatan yang bersifat untuk membangun dan mengembangkan jejaring media dalam rangka meningkatkan citra positif dalam program diskusi dua mingguan.

\section{HUMAS}


Hubungan masyarakat, atau sering disingkat humas adalah seni menciptakan pengertian publik yang lebih baik sehingga dapat memperdalam kepercayaan publik terhadap suatu individu/ organisasi.

Menurut IPRA (International Public Relations Association) Humas adalah fungsi manajemen dari ciri yang terencana dan berkelanjutan melalui organisasi dan lembaga swasta atau publik (public) untuk memperoleh pengertian, simpati, dan dukungan dari mereka yang terkait atau mungkin ada hubungannya dengan penelitian opini public di antara mereka.

Humas adalah sebuah proses yang terus menerus dari usaha-usaha manajemen untuk memperoleh kemauan baik dan pengertian dari pelanggan, pegawai, dan publik yang lebih luas. Dalam pekerjaannya, seorang humas membuat analisis ke dalam dan perbaikan diri, serta membuat pernyataan-pernyataan keluar.

Hubungan masyarakat atau Public Relations adalah suatu usaha yang sengaja dilakukan, direncanakan secara berkesinambungan untuk menciptakan saling pengertian antara sebuah lembaga/institusi dengan masyarakat. Humas (PR) adalah sebuah seni sekaligus ilmu sosial dalam menganalisa kecenderungan, meramalkan konsekuensinya, memberikan pengarahan kepada pimpinan institusi/lembaga dan melaksanakan program-program terencana yang dapat memenuhi kepentingan baik institusi maupun lembaga tersebut maupun masyarakat yang terkait.

Public Relations (PR) merupakan fungsi manajemen untuk mencapai target tertentu yang sebelumnya harus mempunyai program kerja yang jelas dan rinci, mencari fakta, merencanakan, mengkomunikasikan, hingga mengevaluasi hasilhasil apa yang telah dicapainya.

Hubungan masyarakat (Humas) atau Public Relations (PR) adalah sebuah seni berkomunikasi dengan publik untuk membangun saling pengertian, menghindari kesalahpahaman dan mispersepsi, sekaligus membangun citra positif lembaga.

Sebagai sebuah profesi seorang Humas bertanggung jawab untuk memberikan informasi, mendidik, meyakinkan, meraih simpati, dan membangkitkan ketertarikan masyarakat akan sesuatu atau membuat masyarakat mengerti dan menerima sebuah situasi.

\section{HUMAS}

Humas adalah segala bentuk kontak dan hubungan yang diadakan oleh suatu organisasi dengan semua bentuk "publik" baik internal maupun eksternal, hubungan ini adalah meliputi semua bentuk komunikasi. Harus diingatpula, bahwa untuk terbentuknya suatu komunikasi harus terdapat unsur menerima dan memberi" atau dialog - dialog dengan pihak - pihak yang berhubungan, dan unsur - unsur yang ada di dalamnya (humas) adalah: 1)fungsi manajemen, 2) fungsi komunikasi, 3) fungsi penelitian danpenilaian,4) suatu fungsi yang dirancang untuk meningkatkan salingpengertian, keserasian, dan masukan yang demokratis ke dalam suatu proses pengambilan keputusan.Humas bukanlah alat bisnis atau politik, tetapi alat manajemen. Humas juga bukan suatu bentuk reklameatau jurnalisme, meskipin baik advertensi atau reklame dan teknikjurnalistik adalah alat yang dapat dipergunakan untuk meningkatkankomunikasi dalam humas.

Menurut Majalah Public Relations News, humas adalah: fungsi manajemen yang menilai sikap masyarakat,mengidentifikasi karsa dan perilaku individu ataupun suatu organisasiterhadap kepentingan umum, untuk kemudian merencanakan dan melaksanakanprogram aksi untuk mendapatkan pengertian dari masyarakat dengan tujuan agar diterima masyarakat

Menurut " The International Public Relations Assosiation", humas adalah; fungsi manajemen yangberkelanjutan dan terarah lewat sebuah organisasi dan lembaga umummaupun pribadi, berusaha memenangkan dan mempertahankan pengertian,simpati, dan dukungan orang - orang yang mereka inginkan dengan menilaipendapat umum di sekitar mereka sendiri, untuk kemudian dihubungansejauh mungkin dengan karsa dan tingkah lakunya, guna mencapaikerjasama yang lebih produktif dan lebih effisien untuk memenuhi

kepentingan bersama, dengan suatu informasi yang direncanakan dandisebarluaskan.

Menurut The British Institute of Public Relations,humas adalah: suatu usaha yang sengaja dilakukan, direncanakan secaraterus - menerus untuk menciptakan dan memelihara saling pengertianantara sutu organisasi dengan masyarakatnya.

Humas adalah segala bentuk kontak dan hubungan yang diadakan oleh suatu organisasi dengan semua bentuk "publik" baik internal maupun eksternal, hubungan ini adalah meliputi semua bentuk komunikasi. Harus diingatpula, bahwa untuk terbentuknya suatu komunikasi harus terdapat unsur menerima dan memberi" atau dialog - dialog dengan pihak - pihak yang berhubungan, dan unsur - unsur yang ada di dalamnya (humas) adalah: 1)fungsi manajemen, 2) fungsi komunikasi, 3) fungsi penelitian danpenilaian,4) suatu fungsi yang dirancang untuk meningkatkan salingpengertian, keserasian, dan masukan yang demokratis ke dalam suatu proses pengambilan keputusan.Humas bukanlah alat bisnis atau politik, tetapi alat manajemen. Humas juga bukan suatu bentuk reklameatau jurnalisme, meskipin baik advertensi atau reklame dan teknikjurnalistik adalah alat yang dapat dipergunakan untuk meningkatkankomunikasi dalam humas.

\section{STRATEGI HUMAS}

Menurut Cutlip, Center dan Broom (2000) dalam (Ruslan, 2008) , pelaksanaan strategi PR dalam berkomunikasi dikenal dengan istilah "7-Cs PR Communications" dalah sebagi berikut: 
1. Credibility (Kredibilitas)

Komunikasi dimulai dari suasana saling percaya yang diciptakan oleh pihak komunikator secara sungguh-sungguh untuk melayani publiknya yang memiliki keyakinan dan respect.

\section{Context (Konteks)}

Menyangkut sesuatu yang berhubungan dengan lingkungan kehidupan sosial, pesan harus disampaikan dengan jelas serta sikap partisipatif. Komunikasi efektif sangat diperlukan untuk mendukung lingkungan sosial melalui pemberitaan di berbagai media massa.

\section{Content (Isi)}

Isi pesan dalam strategi ini, pesan harus menyangkut kepentingan orang banyak sehingga informasi dapat diterima sebagai sesuatu yang bermanfaat secara umum bagi masyarakat.

\section{Clarity (Kejelasan)}

Pesan disusun dengan kata-kata yang jelas, mudah dimengerti, serta memiliki pemahaman yang sama (maksud, tema dan tujuan) antara komunikator dan komunikan.

5. Continuity and Consistency (Kontinuitas dan Konsistensi)

Komunikasi merupakan proses yang tidak pernah berakhir, oleh karena itu dilakukan secara berulangulang dengan berbagai variasi pesan serta pesanpesan tersebut harus konsisten. Dengan cara demikian, akan mudah proses komunikasi, membujuk publiknya.

\section{Channels (Saluran)}

Menggunakan saluran media yang tepat dan terpercaya serta dipilih oleh khalayak sebagai target sasaran. Pemakaiain saluran media yang berbeda, akan berbeda pula efeknya. Dalam hal ini seorang PR harus memahami perbedaan dan proses penyebaran informasi secara efektif.

\section{Capability of The Audience (Kapabilitas Khalayak) \\ Memperhitungkan kemampuan yang dimiliki oleh khalayak. Komunikasi akan efektif bila beraitan dengan faktor-faktor seperti kebiasaan dan peningkatan kemampuan membaca dan pengembangan pengetahuan khalayak}

\section{CITRA HUMAS}

Menurut (Kotler Philip, 1997)image (citra) adalah kepercayaan, ide dan impresi seseorang terhadap sesuatu. Sedangkan menurut (Buchori Alma, 2007), citra merupakan kesan, opini, pandangan, impresi, perasaan atau persepsi yang ada pada publik mengenai perusahaan, suatu objek orang atau lembaga. Meskipun demikian citra tidak timbul begitu saja, namun memerlukan proses dalam pembentukannya. Bagi sebuah perusahaan, image atau citra yang baik mutlak diperlukan. Sedemikian penting arti dari image (citra) itu sendiri sehingga perusahaan bersedia mengeluarkan biaya dan tenaga ekstra untuk meraihnya. Penilaian atau tanggapan masyarakat tersebut dapat berkaitan dengan timbulnya rasa hormat, kesan-kesan yang baik dan menguntungkan terhadap suatu citra organisasi atau merek produk atau jasa yang diwakili oleh pihak public relations.

Citra adalah tujuan utama dan sekaligus merupakan reputasi dan prestasiyang hendak dicapai public relations. Meskipun demikian pengertian citra itu. sendiri abstrak (intangible) dan tidak dapat diukur secara matematis, tetapi wujudnya bisa dirasakan dari hasil penilaian baik dan buruk (Ruslan, 2007).Biasanya landasan citra itu berakar dari "nilai-nilai kepercayaan" yang kongkretnya diberikan secara individual dan merupakan pandangan atau persepsi.

Proses akumulasi dan amanah kepercayaan yang telah diberikan oleh individu. tersebut akan mengalami proses cepat atau lambat untuk membentuk opini publik yang lebih luas, yaitu sering dinamakan citra.

Citra perusahaan adalah citra dari suatu organisasi secara keseluruhan, jadi bukan citra atas produk dan pelayanannya. Citra adalah tujuan utama, dan sekaligus merupakan reputasi dan prestasi yang hendak dicapai bagi dunia hubungan masyarakat (kehumasan) atau public relations.

Menurut (Kotler Philip, 1985), citra adalah kumpulan dari kepercayaan, ide, pandangan, opini, dan impresi dari seseorang terhadap suatu objek. Pernyataan Kotler menunjukkan bahwa citra adalah serangkaian anggapan, ide gan kesan seseorang terhadap suatu objek sehingga meningkinkan antara seseorang dan orang lainnya mempunyai kesan.

\section{Media Publikasi PR}

A. Media Massa

Media massa seperti yang dikemukakan oleh althusser dan Gramsci dalam Sobur (Sobur, 2004) merupakan alat yang digunakan untuk menyampaikan pendapat atau aspirasi baik itu dari pihak masyarakat maupun dari pihak pemerintah atau negara. media massa tersebut sebagai wadah untuk menyalurkan informasi yang merupakan perwujudan dari hak asasi manusia dalam kehidaupan ermasyarakat dan bernegara, dalam diri mediamassa juga terselubung kepentingan-kepentingan yang lain, misalnya kepentingankapitalisme modal dan kepentingan keberlangsungan lapangan pekerjaan bagi karyawan dan sebagainya.

Media massa mempunyai kekuatan yang sangat signifikan dalam usaha mempengaruhi khlayaknya. Keberadaan media massa mempunyai peranan penting

dalam usaha memberikan informasi penting bagi masyarakat, pengetahuan yang dapat memperluas wawasan, sarana hiburan sebagai pelepas ketegangan, dan yang tidak kalah pentingnya adalah peranan media sebagai kontrol sosial untuk memberikan kritik maupun mendukung 
kebijakan pemerintah agara memotivasi masyarakat. Media massa merupakan institusi baru yang berkaitan dengan produksi dan distribusi pengetahuan dalam arti luas. Media massa mempunyai sejumlah ciri-ciri yang menonjol, diantaranya adalah penggunaan teknologi yang relatif maju untuk produksi (massal) dan penyebaran pesan, mempuyai organisasi yang sistematis dan aturan-aturan sosial serta sasaran pesan yang mengarah pada audiens dalam jumlah besar yang tidak bisa ditentukan apakah meraka menerima pesan yang disampaikan, atau malah menolaknya.

Institusi media massa pada dasarnya terbuka, beroprasi dalam dimensi publik untuk memberikan saluran komunikasi reguler dari berbagai pesan yang mendapat persetujuan sosial dan dikehendaki oleh banyak individu. dalam komunikasi massa menurut Winarni dapat dipusatkan pada komponenkomponen komunikasi massa, yaitu variabel yang dikandung dalam setiap tindak komunikasi dan bagaimana variabel ini bekerja pada media massa,

\section{B. Media Elektronik}

Secara harfiah pengertian media cetak bisa diartikan sebagai sebuah media penyampai informasi yang memiliki dan terkait dengan kepentingan rakyat banyak, yang disampaikan secara tertulis. Dari pengertian ini, kita bisa melihat bahwa media cetak adalah sebuah media yang didalamnya berisi informasi yang terkait dengan kepentingan masyarakat umum dan bukan terbatas pada kelompok tertentu saja. Media cetak ini merupakan bagian dari saluran informasi masyarakat disamping media elektronik dan juga media digital. Dan ditengah dinamika masyarakat yang demikian pesat, media cetak dianggap sudah tertinggal dibandingkan dengan dua pesaingnya yakni media elektronik dan media digital. Meski demikian, bukan berarti media cetak sudah tidak mampu meraih konsumen yang menantikan informasi yang dibawanya.Dan pengertian media cetak tersebut, maka ada keunggulan media ini dibandingkan dua pesaingnya tersebut. Media cetak bisa menyampaikan sebuah informasi secara detail dan terperinci. Sementara untuk media elektronik dan digital, mereka lebih mengutamakan kecepatan informasi. Sehingga tak jarang informasi yang disampaikan lebih bersifat sepotong dan berulang-ulang.

\section{METODE PENELITIAN}

Pada buku (Moleong, 2010) Metodologi kualitatif didefinisikan sebagai prosedur penelitian yang menghasilkan data deskriptif berupa kata-kata tertulis atau lisan dari orang-orang dan perilaku yang diamati. Sedangkan menurut (Kirk dan Miller, 2002) nendefinisikan penelitian kualitatif adalah Tradisi tertentu dalam ilmu pengetahuan sosial yang secara fundamental bergantung pada pengamatan manusia dalam kawasannya sendiri dan berhubungan dengan orang-orang tersebut dalam bahasanya dan peristilahannya".

Kajian tentang definisi-definisi tersebut dapatlah disintesiskan bahwa penelitian kualitatif adalah penelitian yang bermaksud untuk memahami fenomena tentang apa yang dialami oleh subjek penelitian misalnya, perilaku, persepsi, motivasi dan tingkah laku dan lain-lain. Dengan cara deskriptif dalam bentuk kata-kata dan bahasa, pada suatu konteks khusus yang alamiah dan dengan memanfaatkan berbagai metode ilmiah.

Secara umum riset yang menggunakan metodologi kualitatif mempunyai ciri-ciri :

1. Intensif, partisipasi peneliti dalam waktu lama pada setting lapangan, peneliti adalah instrumen pokok riset.

2. Perekaman yang sangat hati-hati terhadap apa yang terjadi dengan catatan-catatan- di lapangan dan tipe-tipe lain dari bukti-bukti dokumenter.

3. Analisis data lapangan.

4. Melaporkan hasil termasuk deskripsi detail, quotes (kutipan-kutipan) dan komentarkomentar.

5. Tidak ada realitas yang tunggal, setiap peneliti mengkerasikan realitas sebagai bagian dari proses penelitiannya. Realitas dipandang sebagai dinamis dan produk konstruksi sosial.

6. Subjektif dan berada hanya dalam referensi peneliti. Peneliti sebagai sarana penggalian interpretasi data.

7. Realitas adalah holistik dan tidak dapat dipilah-pilah.

8. Peneliti memproduksi penjelasan unik tentang situasi yang terjadi dan inividuindividunya.

9. Lebih pada kedalaman (depth) dari pada keluasan (breadth).

10. Prosedur riset : empiris-rasional dan tidak berstruktur.

11. Hubungan antara teori, konsep dan datadata memunculkan atau membentuk teori baru.

Bungin (2014) mengatakan, adapun langkah-langkah penelitian kualitatif yang terdiri dari :

1. Orientasi melalui buku bacaan dan wawancara di lapangan,

2. Eksplorasi, dengan mengumpulkan data, fokus dan penelitian yang jelas,

3. Pengecekan (member check), dengan memeriksa laporan sementara penelitian terhadap responden atau pembimbing dengan tujuan agar memperoleh informasi baru dan dapat menyetujui kebenaran hasil penelitian yang dipercaya.

Tata cara atau strategi untuk mengamati, mengumpulkan informasi dan untuk menyajikan analisis penelitian, penulis menggunakan pendekatan penelitian kualitatif - studi kasus. Penelitian studi kasus atau case study merupakan suatu penelitian yang dilakukan dengan cara intensif mengenai suatu 
unit kasus, seperti individu instansi, suatu masyarakat atau suatu kelompok dimana semua aspek atas unit tersebut yang diteliti.

Menurut Burhan bungin, studi kasus adalah suatu strategi dan metode analisis data kualitatif yang menekankan pada kasus-kasus khusus yang terjadi pada objek analisis.

Penelitian studi kasus data dapat dikumpulkan dengan menggunakan metode observasi, angket, wawancara atau studi kepustakaan. Penulis juga menggunakan desain penelitian deskriptif-kualitatif yaitu untuk mengetahui makna dalam proses-proses komunikasi satu arah (Linier), Interaktif maupun pada proses-proses komunikasi transaksional.

\section{HASIL DAN PEMBAHASAN}

Pada awal kemerdekaan jumlah penduduk yang besar masih sangat diperlukaan sebagai potensi bangsa dan pembangunan, sehingga sikap pemerintah secara tidak langsung membiarkan pertumbuhan penduduk yang cepat dan belum mempertimbangkan pandangan jauh kedepan.

Perkembangan selanjutnya usaha pembangunan ternyata berjalan tidak lancar karena berbagai ketegangan politik dan timbulnya inflasi yang tinggi sehingga membuat indonesia jatuh kedalam kemandegan dan keterbelakangan ekonomi. Di lain pihak masyarakat kita masih beranggapan bahwa jumlah penduduk yang besar masih merupakan potensi dalam mengelola sumber daya alam.

Di indonesia usaha membatasi kelahiran (Birth control) seacara individual telah banyak dilakukan orang secara tradisional. Angka kematian banyak indonesia tergolong tinggi apabila orang sudah mulai merencanakan dan mengatur angka kematian.

Dalam memperkenalkan KB di Indonesia, para tokoh KB umumnya mengaitkan dengan segi kesehatan, sebagai contoh Yayasan Kesejahteraan Keluarga (YKK) yang di dirikan di Yogyakarta pada tanggal 12 November $1952 . \quad$ Dalam perkembangan selanjutnya pelayanan $\mathrm{KB}$ di berikan dibalai kesehatan ibu dan anak (BKIA). Akhirnya dalam menyatakan gerak para tokoh yang mempelopori usah-usaha KB, maka pada tahun 1957 di dirikan perkumpulan Keluarga Berencana Indonesia (PKBI).

Di zaman peradaban manusia yang maju dan modern ini banyak sekali masalah-masalah modern yang sangat mendasar bagi kehidupan. Mulai rusaknya alam, lingkungan sekitar dan menipisnya sumber daya bumi yang ada. Hal ini di akibatkan ulah tangan manusia itu sendiri yang ingin banyak meraup keuntungan agar dapat berlomba-lomba untuk bias hidup dengan layak ditengah masalah ekonomi dunia yang terus menghimpit keadaan banyak manusia di muka bumi ini.

Indonesia, PBB dan dunia sadar bahwa permasalahan kehidupan ini tidak terlepas dari masalah kependudukan. Bertambahnya laju pertumbuhan penduduk dunia membuat Indonesia bahkan dunia terus berpikir keras untuk mengatasi masalah ini secara baik. PBB pun menambahkan bahwa, angka laju pertumbuhan penduduk itu seperti deret ukur.

Namun angka perkembangan tempat lahan dan makanan seperti deret hitung. Hal ini mencerminkan bahwa angka laju pertumbuhan penduduk tidak seimbang dengan perkembangan lahan atau tempat dan makanan.

Paska era kolonialisme dan perang dunia ketiga, Indonesia mulai mencari solusi-solusi terbaik agar bisa mengatasi masalah laju penduduk yang tidak seimbang antara Ibukota dengan Daerah. Mulai dari Transmigrasi, jamunan kesehatan penduduk dan lain sebagainya. Namun hal itu tidak dapat banyak membantu karena masih banyak angka kelahiran yang terjadi.

Tidak sedikit dari mereka yang melahirkan dibawah usia 20 tahun dan banyak pula angka kematian bayi dan ibu karena ada dari mereka yang dibawah usia 20 tahun dan ada juga yang masih melahirkan di atas 35 tahun. Yang kita sama-sama ketahui bahwa dalam usia-usia seperti ini adalah rawan dan banyak resiko persalinan yang akan timbul.

\section{Visi dan Misi BKKBN}

Visi BKKBN adalah Penduduk tumbuh seimbang tahun 2015, Missinya Mewujudkan pembangunan berwawasan kependudukan dan mewujudkan keluarga kecil bahagia dan sejahtera.

\section{Tugas Pokok dan Fungsi BKKBN}

Tugas pokok Melaksanakan pengendalian penduduk dan menyelenggarakan keluarga berencana. Kini fungsi BKKBN menjadi tiga; yaitu dari bidang $\mathrm{KB}$ hanya menjadi demind side, yang menjamin dan menggerakan klien ketempat pelayanan serta menjamin kepuasan bagi mereka. Dan fungsi yang kedua adalah BION family planning yaitu menggerakan kegiatan untuk peserta $\mathrm{KB}$ hanya dengan pendampingan pendataan. Sedangkan fungsi yang ketiga adalah dalam ketahanan keluarga.

\section{Logo BKKBN}

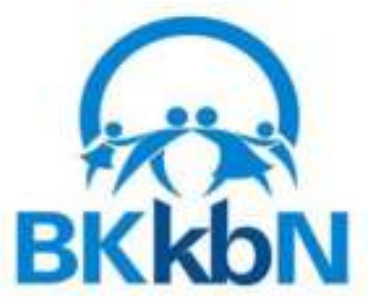

Sumber www.bkkbn.go.id

Gambar 1 Logo BKKBN

Logo BKKBN ini adalah hasil adaptasi dari logo 
terdahulu yag bertujuan untuk mempertegas eksistensi dan peran BKKBN dalam era masa kini yang penuh akan perubahan.

Sebagai lembaga yang berhubungan langsung dengan masyarakat, BKKBN sudah selayaknya mempunyai semangat perubahan untuk mengikuti perkembangan masyarakat yang dinamis dan terus berubah seiring perkembangan zaman.

Perubahan masyarakat yang mengarah pada berkembangnya multi kulturalisme, keragaman komunitas dan pola komunikasi yang partisipatif, haruslah menjadi acuan bagi BKKBN untuk melangkah ke era baru.

\section{PERKEMBANGAN DAN BIDANG KERJA HUMAS}

Sebelum ditetapkannya peraturan perundang-undangan dari amandemen UU belum terjadi perubahan yang significant di BKKBN. Karena perkembangannya pada saat itu masih dijajaran direktorat advokasi yang terdapat di setiap wilayah daerah. Seiring dengan berubahnya status BKKBN maka seluruh elemen di perwakilan BKKBN Provinsi tak terkecuali subbagian umum dan hubungan masyarakat yang berada di bawah naungan seketariat menjadi corong dari lembaga melakukan pemberian dukungan sebagai salah satu tugas administrasi yang meliputi hubungan masyarakat. Karena itu dengan bimbingan teknis dari pusat, Pimpinan BKKBN berusaha untuk memberikan pengarahan tentang tata cara kerja dan ilmu kegiatan humas yang mereka tidak dapatkan sebelumnya agar efektifitas kegiatan humas berjalan sesuai rencana.

\subsubsection{Kedudukan Humas BKKBN}

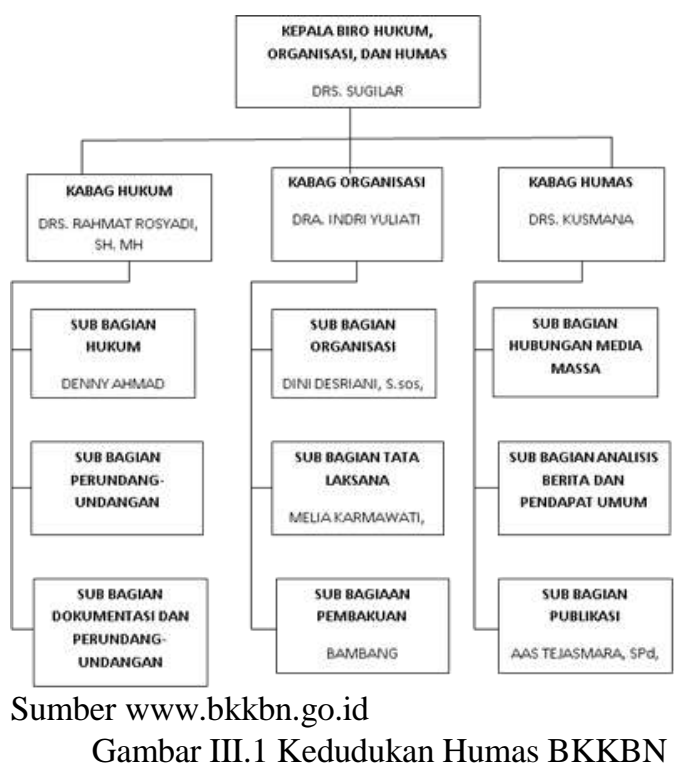

KEDUDUKAN DAN TUGAS HUMAS BKKBN
Humas di BKKBN adalah sebuah jabatan structural dan merupakan unit kerja setingkat esselon 3 yang menjadi sub bagian Biro Hukum, Organisasi, dan Humas. Biro Hukum, Organisasi dan Humas dibagi menjadi 3 bagian yaitu :

1. Sub Bagian Hukum,

2. Sub Bagian Organisasi

3. Sub Bagian Humas

A. Tugas Sub Bagian Hukum :

1.Melakukan penyiapan bahan koordinasi

pelaksanaan kajian dan layanan bantuan hukum

2. Penyiapan koordinasi penelaahan dan penyusunan peraturan perundang undangan

3. Pelaksanaan pengelolaan dokumentasi dan informasi peraturan perundang-undangan.

B. Tugas Sub Bagian Organisasi

1. Melakukan penyiapan koordinasi pelaksanaan pengelolaan organisasi

2. Melakukan penyiapan koordinasi pelaksanaan pengelolaan tata laksana dan pemberian fasilitasi penyusunan norma, standar, prosedur dan kriteria bidang pengendalian penduduk dan penyelenggaraan keluarga berencana.

3. Melakukan penyiapan pelaksanaan pembakuan sarana kerja

C. Tugas Sub Bagian Hubungan Masyarakat

1. Penyiapan koordinasi pelaksanaan hubungan media massa

2. Pelaksanaan analisis berita dan pendapat umum

3. Penyiapan koordinasi pelaksanaan publikasi informasi pengendalian penduduk dan penyelenggaraan keluarga berencana.

\section{PROSES KERJA DAN ANALISIS DATA 1.1 Perencanaan}

1. Analisis situasi

Menurut "Key Informant" Bapak Drs. Kusmana selaku Kepala Bagian Humas BKKBN. BKKBN membentuk suatu program bernama "Diskusi Dua Mingguan", Yang menjadi fokus program ini adalah keluarga kecil bahagia sejahtera atau pasangan usia subur. Program ini bertujuan agar masyarakat dapat mengerti tentang pentingnya program keluarga berencana.dan merubah pola pikir manusia banyak anak banyak rezeki menjadi dua anak lebih baik.

Alasan mengapa memilih media cetak sebagai media partner, karena ada istilah menguasai media sama saja menguasai dunia. Media sebagai suatu alat kekuatan yang bisa menjadi alat untuk pencerahan kepada masyarakat tentang isu citra BKKBN. Tentang isu citra program KB, sehingga bisa di adopt oleh masyarakat menjadi satu perilaku dan perbuatan dalam upaya membutuhkan keluarga kecil bahagia sejahtera. 
Perencanaan ini akan dianalisa SWOT yang terdiri dari :

\begin{abstract}
A.Kekuatan
Menurut key informan Aas Tejasmara, S.pd,MAPS. Bisa kita bilang kekuatan adalah jika kita mempunyai beberapa Link ataupun jaringan dari teman-teman media. Dan apabila minimnya waktu istilah lainnya kepepet mengundang mereka meliput dalam acara dua mingguan untuk hadir kita memberi undangan satu hari sebelum acara, sebagian besar bersedia menghadiri, terkadang teman-teman baru selain yang sudah bergabung bersama group katakan itu, kami bisa mengandalkan mereka untuk memenuhi acara undangan diskusi.
\end{abstract}

\section{B. Kelemahan}

Menurut key informan Aas Tejasmara, S.pd,MAPS Perencanaan waktu muncul awal gagasan tentang acara ini sudah dijadwalkan tetapi kenyataan menjalankan diluar acara tersebut tidak mudah pertama karena narasumber adalah esselon 1 yang masing-masing punya jadwal yang padat jadi, ada yang harus terpaksa mundur atau terpaksa ditukar, sampai mencari narasumber pengganti, ataupun sebelum acara dilaksanakan Humas BKKBN meminta jadwal ke sekretaris masing-masing esselon untuk mengalokasikan waktu.

Yang ke dua dalam pengalaman yang dialami terpaksa menunda karena kegiatan Humas sendiri yang lumayan padat, jadi ada permintaan tools, liputan, presstour, jadi sumber daya tercurah karena takut kegiatan tidak dapat di handle jadi kami terpaksa menunda acara, karena tidak kepastian jadwal, terkadang H-2 baru jadi dilaksanakan.

\section{Ancaman}

Menurut key informan Aas Tejasmara, S.pd,MAPS, ancaman lebih suka dibilang tantangan kalaupun diakatakan sebagai ancaman berkaitan dengan kelemahan ketidak pastian perencanaan dipengaruhi kepastian jadwal sulit dipegang dari rencana kegiatan.

Tantangan mungkin satu sisi kita mengenalkan kerekan-rekan media isu BKKBN itu bukan cuma urusan Keluarga Berencana (KB) saja, kita mengenalkan ke Esselon 1 yang masing-masing mempunyai bidang tugas. Tantangannya adalah mencari isu apa yang merupakan lingkup bidang tugas Esselon 1 yang bersangkutan, ya katakanlah bisa kita jual kerekan-rekan media.

\section{D.Peluang}

Menurut key informan Aas Tejasmara, S.pd,MAPS Acara ini bisa menjadi wadah yang bagus karena kalau dari namanya kita diskusi mungkin bisa dibilang forum, rekan-rekan media bisa kumpul, tukar pikiran diantara mereka sendiri dan antara media dengan BKKBN. adapun hal persepsi yang berbeda, pandangan yang berbeda, acara ini bisa menjadi wadah buat nyamain persepsi. Acara ini akan berlanjut di tambah wajah-wajah baru dari atasan bagi temen media yang belum kenal dan media bisa mengetahui acara- acara kegiatan lainnya.

\section{Tujuan}

Menurut Drs. Kusmana Program ini bertujuan memberikan informasi dan memberikan penceran kepada masyarakat tentang pentingnya keluarga berencana, terutama pada keluarga kecil bersejahtera dan pasangan usia subur bagi yang baru menikah, bahwa pentingnya program KB. Dan menjalin hubungan baik antara BKKBN dengan jurnalis yang bersifat membangun dan mengembangkan jejaring media massa dalam meningkatkan citra positif BKKBN.

\section{Target audience}

Target audience atau sasaran dalam acara diskusi dua mingguan ini adalah media, baik media cetak maupun online. Pemberitaan yang melalui media yang dapat mempengaruhi ke masyarakat.

\section{Pesan}

Merubah tanggapan dan pola pikir masyarakat dan menyadari akan pentingnya program keluarga berencana memberikan pengarahan kepada masyarakat pentingnya keluarga kecil bahagia sejahtera. Intinya BKKBN berpesan agar semua masyarakat Indonesia dapat merencanakan masa depan keluarga dengan baik.

\section{Strategi dan taktik}

Menurut key informan Drs. Kusmana paparan strategi dan taktik yang diberikan adalah :

\section{a.Strategi}

Dalam Situasi yang krodit BKKBN Umunya atau khususnya di bidang Humas akan bekerja sama dengan wartawan agar dapat membuat sebuah pemberitaan yang positif tentang BKKBN agar pencitraan BKKBN sendiri positif di mata masyarakat.

\section{b.Taktik}

taktiknya dilaksankan diawali makan siang wartawannya happy, kemudian diikuti diskusi narasumbernya jadi santai, kemudian editorial meeting strategi taktiknya dilaksanakan ditempat yang menyenangkan tidak terlalu tegang, tidak terlalu formal, dibikin design pertemuan yang tidak serius, kemudian pembawa acaranya dipilih orang-orang yang bisa menggali informasi narasumber dan menggali pertanyaan dari para editor, buat suasana yang santai tapi serius, buat suasana yang bisa menggali semua pemikiranpemikiran dari pihak nara sumber maupun editor, sehingga persoalan-persoalan yang 
menjadi topik diikuti mendapatkan solusi yang terbaik untuk mengangkat citra positif BKKBN.Didalam membangun dan mengembangkan jejaring media masssa taktik lain kita ada hubungan emosional pada jurnalis setiap saat melalui facebook, twitter, telephone, dan lain-lain.

\section{Media}

Menurut Drs. Kusmana selaku Kepala Bagian Humas BKKBN, media yang digunakan dalam diskusi ini tentu saja merupakan media. Media yang melalui press realese, blackberry messanger group, melalui fax, telephone, dan facebook.

\section{Anggaran}

Menurut Drs. Kusmana selaku Kepala Bagian Humas BKKBN, biaya untuk Program Dwi Mingguan ini, dibiayai dengan dana yang bersumber dari APBN biro Hukum, Orhanisasi, dan Hubungan Masyarakat (BIHOM).

\section{Kriteria evaluasi}

Menurut Drs. Kusmana, efektifitas dari evaluasi kegiatan ini sangatlah baik. Merubah sikap perilaku masyarakat dari pandangan negatif tentang alat kontrasepsi menjadi pandangan yang positif tentang keluarga kecil bersejahtera karena masyarakat kita punya asumsi banyak anak banyak rezeki pandangan seperti itu yang susah dirubah karena sudah menjadi suatu budaya. Dalam hal ini BKKBN tidak bekerja sendiri salah satunya bekerja dengan jajaran media karena itu kita mempunyai upaya kegiatan yang bersifat untuk membangun dan mengembangkan jejaring media dalam rangka meningkatkan citra positif.

Tabel III.1

Kriteria Evaluasi

\begin{tabular}{|l|l|l|l|}
\hline No & Tujuan & Program & Indikator \\
\hline 1. & Memberikan & Jejaring & Media banyak \\
& informasi & media & memberikan \\
& kepada & dalam & informasi yang \\
& masyarakat & Program & baik kepada \\
melalui & Diskusi Dua & masyarakat \\
& jejaring media & Mingguan & sebagai \\
khususnya & & jembatan atau \\
pasangan usia & & penghubung \\
subur, dan & & antara BKKBN \\
masyarakat. & & dan masyarakat \\
tentang betapa & & mengenai \\
pentingnya & & program \\
keluarga & & kegiatan yang \\
berencana dan & & di lakukannya. \\
berkurangnya & & Dalam hal ini \\
pandangan & & upaya BKKBN \\
atau citra & & melakukan \\
negatif & & sosialisasinya, \\
masyarakat & & di pandang \\
\hline
\end{tabular}

\begin{tabular}{|l|l|l|}
\hline tentang & & positif oleh \\
BKKBN & masyarakat \\
karena & & \\
program acara & & \\
dua mingguan, & & \\
dan kegiatan- & & \\
kegiatan yang & & \\
dilakukan & & \\
BKKBN. & & \\
\hline
\end{tabular}

\section{PELAKSANAAN}

Menurut Aas Tejasmara, S.pd,MAPS pelaksanaan diadakan sekali dengan pengecualian, penyesuaian dengan jadwal narasumber. Pelaksanaan ini akan diadakan diruang Pers BKKBN yang bertemakan "Menyongsong jendela peluang "Kaum Muda" sebagai investasi".

Acara yang diawali dengan makan siang, selanjutnya penyambutan dari kepala Biro Hukum Organisai dan Hubungan Masyarakat Drs. Sugilar. Dan penyampaian isi materi "Peran Pembangunan Kependudukan Dalam Mencapai Target MDGs" oleh Dr. Wendy Hartanto, MA (Deputi Bidang Pengendalian Penduduk). Yang diakhiri dengan sesi tanya jawab dari wartawan kepada Narasumbernya langsung mengenai tema yang disampaikan.

\section{EVALUASI}

Bapak Drs. Kusmana menyatakan bahwa efektifitas evaluasi kegiatan ini adalah sangat baik. Dengan mengacu pada kriteria evaluasi diatas, beliau pun menyatakan bahwa kegiatan ini berhasil dan pihak eksternal maupun internal banyak mengapresiasi kegiatan tersebut.

Kedepannya acara ini akan terus berjalan seperti yang sudah dilakukan, dengan adanya hal ini respon masyarakat tentang citra positif BKKBN lebih baik. BKKBN dapat menambah kegiatan sosialisasi lewat media cetak dengan mengundang lebih banyak lagi wartawan-wartawan media cetak agar dapat lebih melebarkan publikasi Program-programnya. Jadi bisa dikatakan bahwa kegiatan ini berhasil dilakukan dan juga sangat berpengaruh.

\section{KESIMPULAN}

Berdasarkan hasil riset mengenai "Strategi humas Bkkbn dalam membentuk citra positif melalui media massa koran jakarta" maka penulis dapat menarik kesimpulan sebagai berikut :

1. Badan kependudukan dan keluarga berencana nasional adalah lembaga organisasi pemerintah yang bertugas untuk mencegah laju pertumbuhan penduduk salah satunya dengan mengadakan sosialisasi.

2. Kegiatan yang di lakukan Melalui Media massa ini terbilang lancar, bisa dilihat dari 
berita-berita yang dimuat oleh media cetak atau Koran. Dan yang paling penting adalah kegiatan ini mendapat apresiasi dan respon yang baik dari kalangan masyarakat Indonesia, terutama Pimpinan BKKBN.

3. Humas adalah suatu alat komunikasi perusahaan kepada publik atau masyarakat. Humas sangat dibutuhkan oleh perusahaan / organisasi khususnya BKKBN.

4. Dari kurun waktu usaha yang dilakukan Humas BKKBN menghasilkan nilai positif,program-program yang dilakukan dapat diterima masyarakat tentunya dapat pemberitaan positif dari media.

\section{REFERENSI}

Buchori Alma. (2007). Manajemen pemasaran dan pemasaran jasa. Alfabeta.

Kotler Philip. (1985). Strategic marketing for educational institutionsitle. Prentice-Hall; Edition Unstated edition.

Kotler Philip. (1997). The Marketing of Nations: A
Strategic Approach to Building National Wealth (Vol. 1). Free Press.

Moleong, L. J. (2010). Metode Penelitian Kualitatif. Remaja Rosdakarya.

Ruslan, R. (2007). Kampanye Public Relations. Pt Raja Grafindo persada.

Ruslan, R. (2008). Manajemen Public Relations \& Media Komunikasi: Konsepsi Dan Aplikasi (Edisi Revisi) (Revisi). Rajawali Pers.

Sobur. (2004). Analisis teks media: suatu pengantar untuk analisis wacana, analisis semiotik, dan analisis framing. Remaja Rosda Karya.

\section{PROFIL PENULIS}

Nama Achmad Haikal Lulusan S2 Magister Managemen UBSI Bandung. Mengajar program studi penyiaran Universitas Bina Sarana Informatika dari Tahun 2012 hingga sekarang. 